\title{
Do different strains of $E$. faecalis have the same behavior towards intracanal medications in in vitro research?
}

\section{Rafaela Fernandes ZANCAN ${ }^{(a)}$ Lyz Cristina Furquim CANALI(a) Talita TARTARI (a) \\ Flaviana Bombarda de ANDRADE(a) Rodrigo Ricci VIVAN(a) \\ Marco Antonio Hungaro DUARTE(a)}

(a) Universidade de São Paulo - USP, Bauru Dental School, Department of Restorative Dentistry, Bauru, SP, Brazil.

Declaration of Interest: The authors certify that they have no commercial or associative interest that represents a conflict of interest in connection with the manuscript.

\section{Corresponding Author:}

Rafaela Fernandes Zancan

E-mail: rafaelazancan@yahoo.com.br

https://doi.org/10.1590/1807-3107bor-2018.vol32.0046

Submitted: Aug 23, 2017

Accepted for publication: Mar 15, 2018

Last revision: Apr 13, 2018
Abstract: The aim of this study was to evaluate the antimicrobial action of different endodontic pastes against Enterococcus faecalis ATCC 29212, isolated from the urinary tract, and compare the action with E. faecalis ATCC 4083, isolated from the root canal. For this purpose, dentin blocks were infected for 21 days with both bacteria at different time-intervals to ensure there would be no cross contamination. After this period, blocks were immersed in the test medications for 7 days, according to the following groups: $\mathrm{CH} / \mathrm{S}, \mathrm{CH} / \mathrm{P}, \mathrm{CH} / \mathrm{CMCP}, \mathrm{CH} / \mathrm{CHX}$, $\mathrm{CH} / \mathrm{DAP}$ and TAP. Images of the samples were captured with a confocal microscope and the percentage of live cells was computed by means of the Bioimage program. The ATCC 29212 strain was shown to be more resistant to $\mathrm{CH} / \mathrm{SS}$, Calen, $\mathrm{CH} / \mathrm{DAP}$, and TAP than the ATCC 4083 strain. The antimicrobial action of the medications against each strain were divergent concerning the order of susceptibility. The authors concluded that the strains behaved in a different manner: in general, those extracted from the urinary tract were more resistant to the tested medications. Therefore, when E. faecalis must be used for in vitro research in endodontics, we suggest the use of ATCC 4083 strain to obtain results that are closer to the clinical reality.

Keywords: Enterococcus faecalis; Calcium Hydroxide; Chlorhexidine; Anti-Bacterial Agents; Endodontics.

\section{Introduction}

Inflammatory lesions of the peri-radicular tissues result from an infection caused by the aggressive invasion of microorganisms from the root canal system that resisted the antibodies and immune cells of the host. ${ }^{1}$ Enterococcus faecalis are the bacteria most frequently found in root canals of re-treatment and persistent infection cases, since they are capable of adapting to adverse environments and have a high level of pathogenicity that leads to perpetuation of the endodontic infection. ${ }^{2}$

The application of intracanal medications is one of the strategies used for root canal antisepsis and the most frequently used medication is calcium hydroxide $(\mathrm{CH})$, which releases hydroxyl ions in an aqueous solution, providing a highly alkaline environment that affects most microorganisms in infected root canals. However, microorganisms resistant to $\mathrm{CH}$ such as E. faecalis, ${ }^{3}$ Candida species, ${ }^{4}$ and Actinomyces radicidentis ${ }^{5}$ have been associated with endodontic failure. 
Therefore, to improve its antimicrobial effect, active substances are mixed with $\mathrm{CH}$. Camphorated paramonochlorophenol (CMCP) was suggested as a vehicle in $1966,{ }^{6}$ extending the $\mathrm{CH}$ action to facultative and anaerobic bacteria and improving its ability to penetrate into dentinal tubules. ${ }^{7}$ Chlorhexidine gluconate (CHX) is used as an intracanal irrigant and medicament because of its broad spectrum of activity against Gram-positive and Gram-negative bacteria found in endodontic infections. ${ }^{8}$ Studies have shown the effectiveness of $\mathrm{CHX}$ against microorganisms that are resistant to $\mathrm{CH}$, and the antimicrobial benefits of the mixture of the two products $(\mathrm{CH}+\mathrm{CMCP}) .{ }^{9,10}$

In cases of endodontic failure, the Triple Antibiotic Paste (TAP) containing metronidazole, minocycline, and ciprofloxacin has been suggested. This composition provides powerful action against microorganisms of the oral cavity, ${ }_{11}^{11}$ however, minocycline can cause tooth discoloration. Thus, its exclusion from the paste has been indicated, and the product was called Double Antibiotic Past (DAP). ${ }^{12}$ An alternative that has not been extensively studied is the interaction of the antimicrobial action of DAP with the biological benefits of $\mathrm{CH}$.

The easiness of inducing E. faecalis biofilm in vitro ${ }^{13}$ has increased the interest in studying the resistance of this bacteria to the different substances used in root canal treatment. ${ }^{14,15,16}$ However, the strain used most often is ATCC 29212, isolated from the urinary tract. ${ }^{17,18,19,20}$ With the concern of conducting in vitro research as close as possible to clinical reality, the aim of this study was to evaluate the susceptibility of ATCC 29212 to different intracanal pastes and compare with that of ATCC 4083, which is isolated from the root canal.

The null hypothesis tested were:

a. The strains have the same behavior towards the different pastes;

b. The pastes present similar antimicrobial action.

\section{Methodology}

\section{Obtaining dentin blocks}

Fourteen bovine central incisors with completely developed roots were placed on the bench in a lateral position to provide access to their flattest portion. The roots were then perforated in the cervical and middle thirds by means of a $4 \mathrm{~mm}$ trephine bur
(Neodent, Curitiba, Brazil) coupled to a contra-angle placed perpendicular to the tooth to obtain 4 dentin blocks per tooth. Subsequently, the dentin surfaces were polished with a polishing machine (Arotec, São Paulo, Brazil) and 300 and 600 grit abrasive papers (Buehler, Lake Bluff, USA). Organic residues and dentin scrapings from the cutting procedure were removed with $1 \%$ sodium hypochlorite (Rioquímica Ltda., São José do Rio Preto, Brazil) for 15 minutes, followed by 17\% EDTA (Biodinâmica, Ibiporã, Brazil) for 5 minutes and sterilization in autoclave at $121^{\circ} \mathrm{C}$.

\section{Bacterial growth}

The antimicrobial activity tests were conducted under aseptic conditions in a laminar flow chamber (VecoFlow Ltda, Campinas, SP, Brazil). Each bacterium was manipulated at different time intervals so that there would be no contamination between strains. To activate bacteria, $15 \mu \mathrm{L}$ of each strain (American Type Culture Collection [ATCC] 4083 and [ATCC] 29212) were inserted into $3 \mathrm{~mL}$ of sterile brain-heart infusion (BHI) (Oxoid, Basingstoke, UK) and kept in an oven (model Q816M20; Composto de Quimis Cientıficos Ltda, Diadema, SP, Brazil) at $37^{\circ} \mathrm{C}$ for overnight growth. Afterwards, the bacterial density was adjusted to $10^{8}$ cells/mL with a spectrophotometer (Bel Photonics do Brazil Ltda, Osasco, Brazil) at an optical density of 1 at $600 \mathrm{~nm}$ according to the 0.5 MacFarland standard.

\section{Contamination of the specimens}

Each well of 24-well plates contained 1 dentin block $+0.9 \mathrm{~mL}$ sterile $\mathrm{BHI}+0.1 \mathrm{~mL}$ of the inoculum; plates were kept in an oven (model Q816M20; Composto de Quimis Cientıficos Ltda, Diadema, SP, Brazil) at $37^{\circ} \mathrm{C}$ for 21 days. To avoid nutrient deficiency, the BHI culture medium (Oxoid, Basingstoke, UK) was completely replaced every 48 hours, without the addition of new microorganisms.

\section{Treatment of specimens}

After biofilm maturation, the infected samples were washed with $1 \mathrm{~mL}$ of distilled water to remove loosely adherent and planktonic bacteria. Subsequently, the dentin blocks were immersed in the test medications $(n=5)$ and remained in an oven at $37^{\circ} \mathrm{C}$ for a period of 7 days. The control group received no treatment. 


\section{Intracanal dressings}

a. $\mathrm{G} 1(\mathrm{CH} / \mathrm{S})$ : $\mathrm{CH}$ (calcium hydroxide) (Merck \& Co, Kenilworth, NJ, USA)/ saline $(1 \mathrm{~g} / 0.8 \mathrm{~mL})$;

b. $\mathrm{G} 2(\mathrm{CH} / \mathrm{P})$ : $\mathrm{CH}$ and polyethylene glycol (Calen; SS White Artigos Dentarios Ltd, Rio de Janeiro, Brazil);

c. $\mathrm{G} 3(\mathrm{CH} / \mathrm{CMCP})$ : $\mathrm{CH}$, polyethylene glycol and camphorated paramonochlorophenol (CMCP) (Calen PMCC, SS White Artigos Dentarios Ltd. Rio de Janeiro, Brazil);

d. $\mathrm{G} 4$ (CH/CHX): $\mathrm{CH}$ (Merck \& $\mathrm{Co}), \quad 2 \%$ chlorhexidine gluconate (FGM, Joinville, Brazil) and propylene glycol $(1 \mathrm{~g} / 0.5 \mathrm{~mL} / 0.3 \mathrm{~mL})$;

e. $\mathrm{G} 5(\mathrm{CH} / \mathrm{DAP})$ : $\mathrm{CH}$ (Merck\&Co), Double Antibiotic Paste (Metronidazole, Ciprofloxacin) - Brainfarma Indústria Química e Farmacêutica S.A., São Paulo, Brazil) and Saline (500 mg of each antibiotic/ $500 \mathrm{mg} \mathrm{CH} / 1 \mathrm{~mL}$ );

f. G6 (TAP): Triple Antibiotic Paste (Metronidazole, Ciprofloxacin, Minocycline - Brainfarma Indústria Química e Farmacêutica S.A., São Paulo, Brazil) and Saline (500 $\mathrm{mg}$ of each antibiotic/ $1 \mathrm{~mL}$ ).

\section{Microbiological Analysis}

The samples were washed with PBS (phosphate buffer solution) to remove the pastes and residues and then stained with $15 \mu \mathrm{L}$ of SYTO9 and propidium iodide solution (Live/Dead BacLight Viability Kit; Molecular Probes, Eugene, USA) for 15 minutes.SYTO911 is a selective nucleic acid fluorescent stain, indicated for staining live and dead cells (general stain) and propidium iodide identifies microbial populations with an affected cellular membrane or dead cells, and presents a red fluorescence. On entering the cells, the red fluorescence diminishes the fluorescence of SYTO9 leaving the dead cells with a red or yellowish fluorescence. After staining, 4 images per dentin block totaling 20 images per group were captured by means of a Laser Scanning Confocal Microscope (LSCM) (Laica, Mannheim, Germany) at 40x magnification. The percentage of live and dead bacteria was obtained by means of Bioimage v2-1 software (www.bioImageL.com).

\section{Results}

Figure shows confocal laser scanning microscopy of the biofilms treated with the tested intracanal dressings: $(\mathrm{CH} / \mathrm{S})$ calcium hydroxide + saline solution, $(\mathrm{CH} / \mathrm{P})$ calcium hydroxide + polyethylene glycol, $(\mathrm{CH} / \mathrm{CMCP})$ calcium hydroxide + polyethylene glycol $+\mathrm{CMCP}$, $(\mathrm{CH} / \mathrm{CHX})$ calcium hydroxide + propylene glycol + chlorhexidine, (CH/DAP) calcium hydroxide + Double Antibiotic Paste, (TAP) Triple Antibiotic Paste and (CG) control group. Enterococcus faecalis biofilm (ATCC 29212) and Enterococcus faecalis biofilm (ATCC 4083) are identified by numbers 1 an 2 , respectively. Live cells are indicated in green, and dead cells are indicated in red.

Table 1 shows the percentage of viable cells of different biofilms after a one-week treatment with the medications. The ATCC 29212 strain showed more resistance to the $\mathrm{CH} / \mathrm{S}, \mathrm{CH} / \mathrm{P}, \mathrm{CH} / \mathrm{DAP}$, and TAP pastes than the ATCC 4083 strain, without statistical differences among the other groups.

The order of susceptibility to the medications from high to low was TAP, CH/S, CH/CMCP, CH/ $\mathrm{CHX}, \mathrm{CH} / \mathrm{P}$, and CH/DAP for ATCC 29212 and TAP, $\mathrm{CH} / \mathrm{S}, \mathrm{CH} / \mathrm{CHX}, \mathrm{CH} / \mathrm{P}, \mathrm{CH} / \mathrm{CMCP}$, and $\mathrm{CH} / \mathrm{DAP}$ for ATCC 4083.

\section{Discussion}

The null hypotheses were rejected because:

a. Differences were observed in the susceptibility of E. faecalis ATCC 4083 and ATCC 29212 to the studied pastes;

b. The pastes presented different antimicrobial action.

Enterococcus faecalis is a Gram-positive, facultative anaerobic bacterium that presents in pairs in the coccus form, or in short chains in the planktonic form. ${ }^{2,21,22}$ It is also capable of easily organizing itself into a biofilm, which increases its resistance to chemical-physical root canal treatments and alkaline environments, as in the case of intracanal medications with $\mathrm{CH}^{16}$ When these bacteria are exposed to unfavorable conditions, such as nutritional limitation, they go into "starvation phase/mode" and are capable of resisting for up to 12 months within dentinal tubules, even after the filling of the root canal system. ${ }^{23,24}$

Endodontic pathogens are micro-organisms able to penetrate enamel, dentin and pulp, and establish and survive in the root canal space. ${ }^{25}$ The ability of E. faecalis to adapt to external factors ${ }^{1}$ and its high virulence result in a high degree of pathogenicity, ${ }^{13,26}$ with an advantage over other microorganisms found 

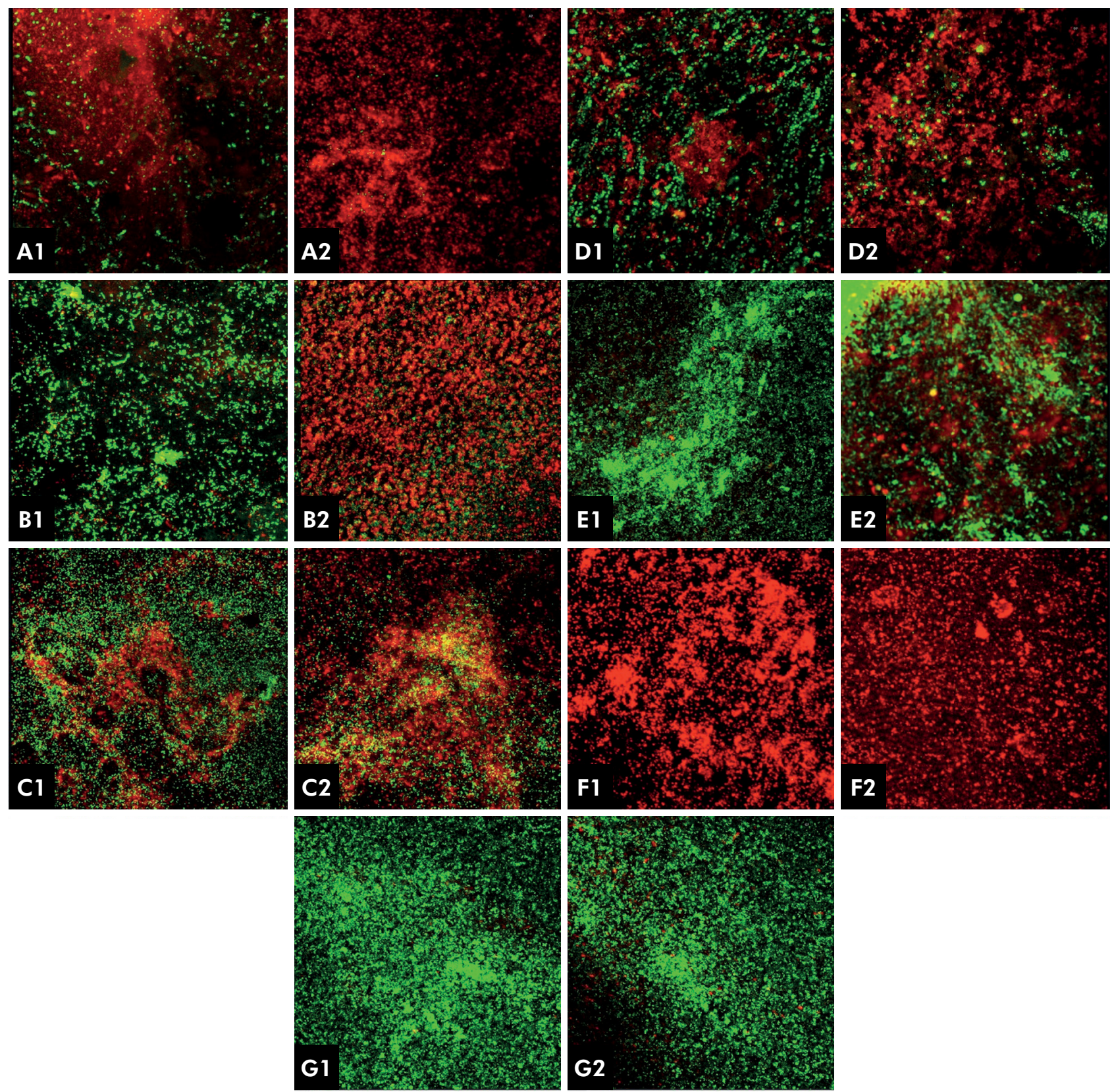

Figure.- Confocal laser scanning microscopy of biofilms treated with (A) calcium hydroxide + saline solution, (B) calcium hydroxide + polyethylene glycol, (C) calcium hydroxide + polyethylene glycol $+\mathrm{CMCP}$, and (D) calcium hydroxide + propylene glycol $+\mathrm{CHX}$, (E) DAP $+\mathrm{CH}$, (F) TAP, and (G) control group. Number 1 corresponds to Enterococcus faecalis biofilm (ATCC 29212) and number 2 to Enterococcus faecalis biofilm (ATCC 4083). Live cells are indicated in green, and dead cells are indicated in red. Each picture represents an area of $275 \times 275 \mu \mathrm{m}$.

Table. Median (Med), minimum and maximum (Min-Max) values of the percentage of live cells of different biofilms after contact with the experimental medicaments for a week.

\begin{tabular}{lccccccc}
\hline ATCC & Control & $\mathrm{CH} / \mathrm{S}$ & $\mathrm{CH} / \mathrm{P}$ & $\mathrm{CH} / \mathrm{CMCP}$ & $\mathrm{CH} / \mathrm{CHX} 2 \%$ & $\mathrm{CH} / \mathrm{DAP}$ & TAP \\
\hline \multirow{2}{*}{4083} & 75.59 & 13.15 & 44.64 & 52.94 & 35 & 59.98 & 0.06 \\
& $(42.9-96.5)^{\mathrm{aA}}$ & $(0.21-53.10)^{\mathrm{bCD}}$ & $(4.08-92)^{\mathrm{bABC}}$ & $(8.14-82.4)^{\mathrm{aAB}}$ & $(8.44-77.6)^{\mathrm{aBC}}$ & $(11.46-80.3)^{\mathrm{bAB}}$ & $(0.001-1.23)^{\mathrm{bD}}$ \\
29212 & 86.75 & 34.52 & 71.9 & 58.26 & 45.8 & 83.73 & 10.42 \\
& $(26.9-99.9)^{\mathrm{aA}}$ & $(3.99-92.9)^{\mathrm{aCD}}$ & $(5.54-96.91)^{\mathrm{aAC}}$ & $(0-98.95)^{\mathrm{aBCD}}$ & $(7.1-98)^{\mathrm{aBC}}$ & $(24.02-93.4)^{\mathrm{aAB}}$ & $(0.2-47.84)^{\mathrm{aD}}$ \\
\hline
\end{tabular}

*Kruskal-Wallis with Dunn's post-hoc. P-value < 0.05; Different capital letters in rows indicate statistically significant intergroup differences in the same biofilm. Different lower letters in columns indicate statistically significant intragroup differences between biofilms. 
during the different stages of endodontic treatment; thus, it is considered "the villain" of endodontics. ${ }^{2}$ Indeed, although primary endodontic infection is caused by a mixed community of microorganisms such as Firmicutes, Bacteroidetes, Spirochaetes, Fusobacteria, Actinobacteria, Proteobacteria, Synergistes, TM7 and $S R 1,27,28$ the main microorganism isolated in cases of endodontic treatment failure is E. faecalis, with a prevalence of 24 to $77 \% .^{29,30,31}$

Given the resistance of E. faecalis to endodontic treatment, this microorganism has frequently been used in in vitro research in the planktonic or biofilm form. ${ }^{16,17}$ A biofilm is a thin layer of microorganisms adhering to the surface of a structure enclosed in a extracellular matrix (ECM) that increases its resistance to environment stresses. All strains of E. faecalis produce ECM in aerobic conditions; however, the amount produced varies depending on the isolate, environment, biofilm complexity, and substrate. ${ }^{25}$ The ATCC (American Type Culture Collection) lists 69 commercially available strains of E. faecalis. A strain is a descriptive subdivision of a species and when it undergoes significant mutations or as it adapts to new environmental conditions, the descendants may form new strains, which are clonally related isolates, since they have common phenotypes and genotypes. ${ }^{32,33}$ Each of these isolates has an ATCC number and different hereditary characteristics arising from absorption of molecules or their fragments of DNA disposed in their respective environments. ${ }^{2}$

Distinct prevalence patterns of virulence genes of Enterococcus spp. have been isolated from root canals with treatment failure. The different expression profiles of these virulence factors with intermediate/total resistance to several antimicrobial agents can be explained by environmental factors such as geographic differences and dietary habits. ${ }^{34,35}$ Moreover, endodontic bacterial species are arranged close to one another, which is highly conducive to establishing interactions such as food chains, quorum-sensing systems, and exchange of genes related to virulence and antibiotic resistance. ${ }^{36}$ Thus, the infection of teeth can have an influence on the microbiota and consequently on the type of the virulence exchanged by bacteria. Associations have been reported between endodontic bacterial species and antibiotic resistance, including Prevotella species from dentoalveolar abscesses ${ }^{37}$ and Enterococcus faecalis from teeth with post-treatment apical periodontitis. ${ }^{38}$ This is important for understanding the pathogenicity of virulence factors and their effects on the host.

Due to the concern related to the accuracy of in vitro research and the different patterns of virulence and resistance genes of $E$. faecalis strains, their monitoring should be encouraged for establishing the most effective drug. In this study, the behavior of a $E$. faecalis lineage originally isolated from root canal infection - ATCC 4083 15,16 - was compared with that of ATCC 29212 (isolated from urine), which is used in most studies. ${ }^{17,18,19,39}$

In general, we observed that ATCC 29212 was more resistant than ATCC 4083. (Table). One of the main mechanisms of $\mathrm{CH}$ antimicrobial action - within an inert vehicle - is the alkalinization of the medium. ${ }^{6}$ Many diseases, diets, and medications make urine acidic or basic, which may justify the greater resistance of ATCC 29212 (isolated from urine) to changes in $\mathrm{pH}$ caused by the $\mathrm{CH} / \mathrm{SS}$ and $\mathrm{CH} / \mathrm{P}$ pastes in comparison with ATCC 4083 (isolated from the root canal).

Camphorated paramonochlorophenol (CMCP) is a widely used vehicle that increases the $\mathrm{CH}$ paste spectrum of action, improving the ability of $\mathrm{Ca}^{2+}$ and $\mathrm{OH}$-ions to penetrate dentinal tubules. ${ }^{40}$ Chlorhexidine (CHX) presents a broad antimicrobial spectrum and has excellent antimicrobial activity at $\mathrm{pH}$ between 5.5 and $77^{14}$ However, in an alkaline environment, CHX may decompose into reactive by-products such as reactive oxygen compounds that may also kill E. faecalis. ${ }^{41}$ In the groups with active vehicles (camphorated paramonochlorophenol and chlorhexidine) added to $\mathrm{CH}$ pastes, there was no statistical difference between the two bacterial strains relative to the percentage of live cells. However, when we compared the susceptibility of bacteria to the different pastes, results were divergent, since the antimicrobial action of the $\mathrm{CH} / \mathrm{CMCP}$ paste was better than CH/CHX for ATCC 29212, and the association of $\mathrm{CHX}$ showed advantages over $\mathrm{CMCP}$ for ATCC 4083.

A higher prevalence of live cells was found for ATCC 29212 when the two bacteria were compared regarding the antibiotic pastes. The indiscriminate use of antimicrobial agents is responsible for the 
development of microbial resistance. ${ }^{42}$ Antibiotics are frequently taken by the systemic route and excreted through urine, which may justify the results. ${ }^{43}$ The TAP paste is used in the topical form in root canal systems, and contains ciprofloxacin, metronidazole, and minocycline. It is indicated in cases of antimicrobial resistance because of its broad spectrum of action. ${ }^{4}$ As minocycline can cause discoloration of teeth, the combination of metronidazole and ciprofloxacin, called DAP, has solved this problem. ${ }^{45}$ Researchers have found no difference between antimicrobial activities of these antibiotic pastes. ${ }^{44,46}$

However, in this study, the DAP paste was used in association with $\mathrm{CH}$. When we compared the order of bacterial resistance in relation to the pastes, we found that TAP and $\mathrm{CH} / \mathrm{DAP}$ had the best and worst antimicrobial result, respectively. TAP significantly reduced cell viability, differently from $\mathrm{CH} / \mathrm{DAP}$ that showed results similar to the control. The alkaline environment provided by the addition of $\mathrm{CH}$ to DAP probably influenced the ability of the antibiotic to penetrate into the bacterial cells.

Nevertheless, the authors concluded in general that the strain isolated from the urinary tract (ATCC 29212) was more resistant than that isolated from the root canal (ATCC 4083) and behaved in a different manner in relation to the order of resistance to medications, as was the case of $\mathrm{CH} / \mathrm{CHX}$ and $\mathrm{CH} / \mathrm{CMCP}$ treatments. Therefore, evaluation of the susceptibility to antibiotics is important to understand and control the propagation of endodontic diseases. For in vitro research, the use of strains isolated from the root canal is recommended, since different strains of the same species may differ due to acquired characteristics.

\section{Acknowledgement}

This study was supported by the FAPESP grant 2016/25133-1.

\section{References}

1. Chavez de Paz LE. Redefining the persistent infection in root canals: possible role of biofilm communities. J Endod. 2007 Jun;33(6):652-62. https://doi.org/10.1016/i.joen.2006.11.004

2. Stuart CH, Schwartz SA, Beeson TJ, Owatz CB. Enterococcus faecalis: its role in root canal treatment failure and current concepts in retreatment. J Endod. 2006 Feb;32(2):93-8. https://doi.org/10.1016/j.joen.2005.10.049

3. Evans M, Davies JK, Sundqvist G, Figdor D. Mechanisms involved in the resistance of Enterococcus faecalis to calcium hydroxide. Int Endod J. 2002 Mar;35(3):221-8. https://doi.org/10.1046/j.1365-2591.2002.00504.x

4. Waltimo TM, Sirén EK, Orstavik D, Haapasalo MP. Susceptibility of oral Candida species to calcium hydroxide in vitro. Int Endod J. 1999 Mar;32(2):94-8. https://doi.org/10.1046/j.1365-2591.1999.00195.x

5. Kalfas S, Figdor D, Sundqvist G. A new bacterial species associated with failed endodontic treatment: identification and description of Actinomyces radicidentis. Oral Surg Oral Med Oral Pathol Oral Radiol Endod. 2001 Aug;92(2):208-14. https://doi.org/10.1067/moe.2001.117268

6. Frank AL. Therapy for the divergent pulpless tooth by continued apical formation. J Am Dent Assoc. 1966;72(1):87-93. https://doi.org/10.14219/jada.archive.1966.0017

7. Taylor GN, Madonia JV, Wood NK, Hever MA. In vivo autoradiographic study of relative penetrating abilities of aqueous $2 \%$ parachlorophenol and cambhorated
35\% parachlorophenol. J Endod. 1976 Mar;2(3):81-6. https://doi.org/10.1016/S0099-2399(76)80202-6

8. Estrela CR, Estrela C, Reis C, Bammann LL, Pécora JD. Control of microorganisms in vitro by endodontic irrigants. Braz Dent J. 2003;14(3):187-92. https://doi.org/10.1590/S0103-64402003000300009

9. Ercan E, Dalli M, Dülgergil CT. In vitro assessment of the effectiveness of chlorhexidine gel and calcium hydroxide paste with chlorhexidine against Enterococcus faecalis and Candida albicans. Oral Surg Oral Med Oral Pathol Oral Radiol Endod. 2006 Aug;102(2):e27-31. https://doi.org/10.1016/i.tripleo.2006.02.022

10. Delgado RJ, Gasparoto TH, Sipert CR, Pinheiro CR, Moraes IG, Garcia RB et al. Antimicrobial effects of calcium hydroxide and chlorhexidine on Enterococcus faecalis. J Endod. 2010 Aug;36(8):1389-93. https://doi.org/10.1016/i.joen.2010.04.013

11. Windley W 3rd, Teixeira F, Levin L, Sigurdsson A, Trope M. Disinfection of immature teeth with a triple antibiotic paste. J Endod. 2005 Jun;31(6):439-43. https://doi.org/10.1097/01.don.0000148143.80283.ea

12. Akcay M, Arslan H, Yasa B, Kavrık F, Yasa E. Spectrophotometric analysis of crown discoloration induced by various antibiotic pastes used in revascularization. J Endod. 2014 Jun;40(6):845-8. https://doi.org/10.1016/i.joen.2013.09.019 
13. Portenier I, Waltimo T, Ørstavik D, Haapasalo M. The susceptibility of starved, stationary phase, and growing cells of Enterococcus faecalis to endodontic medicaments. J Endod. 2005 May;31(5):380-6. https://doi.org/10.1097/01.don.0000145421.84121.c8

14. Gomes BP, Souza SF, Ferraz CC, Teixeira FB, Zaia AA, Valdrighi $L$ et al. Effectiveness of $2 \%$ chlorhexidine gel and calcium hydroxide against Enterococcus faecalis in bovine root dentine in vitro. Int Endod J. 2003 Apr;36(4):267-75. https:// doi.org/10.1046/i.1365-2591.2003.00634.x

15. Hoelscher AA, Bahcall JK, Maki JS. In vitro evaluation of the antimicrobial effects of a root canal sealer-antibiotic combination against Enterococcus faecalis. J Endod. 2006 Feb;32(2):145-7. https://doi.org/10.1016/i.joen.2005.10.031

16. Zancan RF, Vivan RR, Milanda Lopes MR, Weckwerth PH, Andrade FB, Ponce JB et al. Antimicrobial activity and physicochemical properties of calcium hydroxide pastes used as intracanal medication. J Endod. 2016 Dec;42(12):1822-8. https://doi.org/10.1016/i.joen.2016.08.017

17. Cobankara FK, Altinöz HC, Ergani O, Kav K, Belli S. In vitro antibacterial activities of root-canal sealers by using two different methods. J Endod. 2004 Jan;30(1):57-60. https:// doi.org/10.1097/00004770-200401000-00013

18. Eldeniz AU, Hadimli HH, Ataoglu H, Orstavik D. Antibacterial effect of selected root-end filling materials. J Endod. 2006 Apr;32(4):345-9. https://doi.org/10.1016/i.joen.2005.09.009

19. Al-Hezaimi K, Al-Shalan TA, Naghshbandi J, Oglesby S, Simon JH, Rotstein I. Antibacterial effect of two mineral trioxide aggregate (MTA) preparations against Enterococcus faecalis and Streptococcus sanguis in vitro. J Endod. 2006 Nov;32(11):10536. https://doi.org/10.1016/i.joen.2006.06.004

20. Latham J, Fong $H$, Jewett A, Johnson JD, Paranipe A. Disinfection efficacy of current regenerative endodontic protocols in simulated necrotic immature permanent teeth. J Endod. 2016 Aug;42(8):1218-25. https://doi.org/10.1016/i.joen.2016.05.004

21. Smyth CJ, Matthews $H$, Halpenny MK, Brandis $H$, Colman $\mathrm{G}$. Biotyping, serotyping and phage typing of Streptococcus faecalis isolated from dental plaque in the human mouth. J Med Microbiol. 1987 Feb;23(1):45-54. https://doi.org/10.1099/00222615-23-1-45

22. Gomes BP, Pinheiro ET, Sousa EL, Jacinto RC, Zaia AA, Ferraz CC et al. Enterococcus faecalis in dental root canals detected by culture and by polymerase chain reaction analysis. Oral Surg Oral Med Oral Pathol Oral Radiol Endod. 2006 Aug;102(2):247-53. https://doi.org/10.1016/i.tripleo.2005.11.031

23. Sedgley CM, Lennan SL, Appelbe OK. Survival of Enterococcus faecalis in root canals ex vivo. Int Endod J. 2005 Oct;38(10):73542. https://doi.org/10.1111/j.1365-2591.2005.01009.x

24. Noguchi N, Noiri Y, Narimatsu M, Ebisu S. Identification and localization of extraradicular biofilm-forming bacteria associated with refractory endodontic pathogens. Appl Environ Microbiol. 2005 Dec;71(12):8738-43. https://doi.org/10.1128/AEM.71.12.8738-8743.2005
25. Yoo A, Rossi-Fedele G, Kidd SP, Rogers AH, Zilm PS. Association between extracellular material and biofilm formation in response to sodium hypochlorite by clinical isolates of Enterococcus faecalis. J Endod. 2018 Feb;44(2):269-73. https://doi.org/10.1016/i.joen.2017.08.025

26. de Melo Maltos SM, Ribeiro Sobrinho AP, Silva FV, Nicoli JR, Carvalho MAR, Vieira $L Q$ et al. Bacterial concentrations determine the ability to implant in the root canal system and translocate to lymph nodes in germ-free mice. J Endod. 2003 Jan;29(1):24-7. https://doi.org/10.1097/00004770-200301000-00007

27. Fabricius L, Dahlén G, Ohman AE, Möller AJ. Predominant indigenous oral bacteria isolated from infected root canals after varied times of closure. Scand J Dent Res. 1982 Apr;90(2):134-44.

28. Lana MA, Ribeiro-Sobrinho AP, Stehling R, Garcia GD, Silva $\mathrm{BK}$, Hamdan JS et al. Microorganisms isolated from root canals presenting necrotic pulp and their drug susceptibility in vitro. Oral Microbiol Immunol. 2001 Apr;16(2):100-5. https://doi.org/10.1034/j.1399-302x.2001.016002100.x

29. Siren EK, Haapasalo MP, Ranta K, Salmi P, Kerosuo EN. Microbiological findings and clinical treatment procedures in endodontic cases selected for microbiological investigation. Int Endod J. 1997 Mar;30(2):91-5. https://doi.org/10.1111/j.1365-2591.1997.tb00680.x

30. Sundqvist G, Figdor D, Persson S, Siögren U. Microbiologic analysis of teeth with failed endodontic treatment and the outcome of conservative re-treatment. Oral Surg Oral Med Oral Pathol Oral Radiol Endod. 1998 Jan;85(1):86-93. https://doi.org/10.1016/S1079-2104(98)90404-8

31. Pinheiro ET, Gomes BP, Ferraz CC, Sousa EL, Teixeira FB, Souza-Filho FJ. Microorganisms from canals of root-filled teeth with periapical lesions. Int Endod J. 2003 Jan;36(1):1-11. https://doi.org/10.1046/j.1365-2591.2003.00603.x

32. Barrett TJ, Lior H, Green JH, Khakhria R, Wells JG, Bell BP et al. Laboratory investigation of a multistate food-borne outbreak of Escherichia coli $\mathrm{O} 157: \mathrm{H7}$ by using pulsed-field gel electrophoresis and phage typing. J Clin Microbiol. 1994 Dec;32(12):3013-7.

33. Tenover FC, Arbeit RD, Goering RV, Mickelsen PA, Murray BE, Persing $\mathrm{DH}$ et al. Interpreting chromosomal DNA restriction patterns produced by pulsed-field gel electrophoresis: criteria for bacterial strain typing. J Clin Microbiol. 1995 Sep;33(9):2233-9.

34. Wang L, Dong M, Zheng J, Song Q, Yin W, Li J et al. Relationship of biofilm formation and gelE gene expression in Enterococcus faecalis recovered from root canals in patients requiring endodontic retreatment. J Endod. 2011 May;37(5):631-6. https://doi.org/10.1016/i.joen.2011.02.006

35. Sedgley CM, Molander A, Flannagan SE, Nagel AC, Appelbe OK, Clewell DB et al. Virulence, phenotype and genotype characteristics of endodontic Enterococcus spp. Oral Microbiol Immunol. 2005 Feb;20(1):10-9. https://doi.org/10.1111/i.1399-302X.2004.00180.x

36. Marsh PD. Dental plaque: biological significance of a biofilm and community life-style. J Clin Periodontol. 2005;32(s6 Suppl 6):7-15. https://doi.org/10.1111/j.1600-051X.2005.00790.x 
Do different strains of E. faecalis have the same behavior towards intracanal medications in in vitro research?

37. Iwahara K, Kuriyama T, Shimura S, Williams DW, Yanagisawa $\mathrm{M}$, Nakagawa K et al. Detection of cfxA and cfxA2, the betalactamase genes of Prevotella spp., in clinical samples from dentoalveolar infection by real-time PCR. J Clin Microbiol. 2006 Jan;44(1):172-6. https://doi.org/10.1128/JCM.44.1.172-176.2006

38. Pinheiro ET, Gomes BP, Drucker DB, Zaia AA, Ferraz CC, Souza-Filho FJ. Antimicrobial susceptibility of Enterococcus faecalis isolated from canals of root filled teeth with periapical lesions. Int Endod J. 2004 Nov;37(11):756-63. https://doi.org /10.1111/i.1365-2591.2004.00865.xPMID:15479258

39. Ferreira FB, Torres SA, Rosa OP, Ferreira CM, Garcia RB, Marcucci MC et al. Antimicrobial effect of propolis and other substances against selected endodontic pathogens. Oral Surg Oral Med Oral Pathol Oral Radiol Endod. 2007 Nov;104(5):709-16. https://doi.org/10.1016/j.tripleo.2007.05.019

40. Lima RA, Carvalho CB, Ribeiro TR, Fonteles CS. Antimicrobial efficacy of chlorhexidine and calcium hydroxide/camphorated paramonochlorophenol on infected primary molars: a split-mouth randomized clinical trial. Quintessence Int. 2013 Feb;44(2):113-22. https://doi.org/10.3290/i.qi.a28932

41. Barbin LE, Saquy PC, Guedes DF, Sousa-Neto MD, Estrela C, Pécora JD. Determination of para-chloroaniline and reactive oxygen species in chlorhexidine and chlorhexidine associated with calcium hydroxide. J Endod. 2008 Dec;34(12):1508-14. https://doi.org/10.1016/i.joen.2008.08.032

42. Magyar A, Köves B, Nagy K, Dobák A, Arthanareeswaran VK, Bálint $P$ et al. Spectrum and antibiotic resistance of uropathogens between 2004 and 2015 in a tertiary care hospital in Hungary. J Med Microbiol. 2017 Jun;66(6):788-97. https://doi.org/10.1099/jmm.0.000498

43. Villani F, Bohnet A, Sakellaridès E, Schelling JL. [Urinary concentration and antibacterial effect of short and long acting tetracycyline]. Schweiz Med Wochenschr. 1975 Mar;105(11):341-4. French.

44. A Algarni A, H Yassen G, L Gregory R. Inhibitory effect of gels loaded with a low concentration of antibiotics against biofilm formation by Enterococcus faecalis and Porphyromonas gingivalis. J Oral Sci. 2015 Sep;57(3):213-8. https://doi.org/10.2334/josnusd.57.213

45. Kahler B, Rossi-Fedele G. A review of tooth discoloration after regenerative endodontic therapy. J Endod. 2016 Apr;42(4):563-9. https://doi.org/10.1016/i.joen.2015.12.022

46. Sabrah AH, Yassen GH, Gregory RL. Effectiveness of antibiotic medicaments against biofilm formation of Enterococcus faecalis and Porphyromonas gingivalis. J Endod. 2013 Nov;39(11):1385-9. https://doi.org/10.1016/i.joen.2013.05.003 